\title{
THE IMPACT OF ORGANIC AGRICULTURE ON THE QUALITY CHARACTERISTICS OF SOME FRUITS, VEGETABLES AND MEDICINAL PLANTS \\ Mohsen,S. M. ${ }^{*}$ M. A. Haseeb** andS. A. Abulroos ** \\ *Department of Food Science,Faculty of Agriculture Cairo University, Gyza, Egypt \\ ${ }^{* \star}$ Department of Soil Sciences, Faculty of Agriculture Cairo University, Giza, Egypt
}

\begin{abstract}
In the present study physical and chemical characteristics of orange fruits, tomato, green beans, fennel and lemongrass as affected by organic agriculture were studied. The phytochemicals characteristics of orange and tomato juice were also determined in the organic samples compared to conventional products. The results showed thatorganic management decreased the percentage of peels and reducing sugars and increased juice percentages and ascorbic acid in organic orange fruits. In addition organic orange juice had better taste, odor and texture. Organic management also decreased the weight of peel and pulp and the percentage of TSS and increased juice percentage and the content of ascorbic acid, total phenol and lycopen in tomato as compared to conventional management.Organic managementof green beans increased percentage of protin, starch, reducing sugar and total sugarcompared toconventionalmanagement .Organic management of lemon grass increased the oil percentage, the percentage of a-Myrcene, and Citral and decreased Anethole(Estragole) content as compared to the conventional product.Organic management of fennel increased the percentage of Anethole and decreased the percentage of D-Limonene in the oil as compared to conventional one.
\end{abstract}

\section{INTRODUCTION}

There is a growing interest for organic farming in Europe and other parts of the world. Consumers are constantly looking for the safe foods rich in the numerous beneficial substances with high quality. There were scientific indications that vegetables and fruits from organic production could contain more beneficial substances (such as poly phenols and ascorbic acid) than crops from the conventional one.

Different studies were carried out to compare between organic and conventional crops characteristic with respect to safety and nutritional value. How does agriculture affect nutrient composition? Are agricultural chemicals responsible for the decrease in nutrient content? A number of studies over the last 75 years have addressed the question of whether agricultural chemicals and other agricultural methods including organic farming affect nutrient content. The question is still unresolved in part due to the large amount of variability in agricultural data resulting from uncontrollable factors such as rainfall and sunlight, which also influence nutrient content. In addition, few existing studies are exactly alike or even very similar as there are differences in crops grown, fertilization methods used, storage methods if 
any, etc. These factors could make it hard to interpret data from these studies in any conclusive manner.

Recently there have been identified changes in the nutrient composition of fresh fruits and vegetables grown under conventional agriculture system. It is claimed that organic foods contained a better arrangement of nutrients as a result of the superior soil management and fertilization practices used by organic farmers.

Worthington (2001), Bourn and Prescott, 2002; Magkoset al. (2003) and (Pérez-Lópezet al., 2007) found that organic crops contained significantly more vitamin $\mathrm{C}$, iron, magnesium, and phosphorus and less nitrates than conventional crops. Worthington (2001) and Strackeet al. (2008) found that the amount of total proteins in organically produced crops were lower than those of conventional produced one. In general, citrus fruits produced in organic farms had greater juice percentage (Lester et al., 2007; Roussos 2011).Kumpulainen (2001)andBordeleauet al. (2002) found no taste difference in potatoes, lettuce, green beans, broccoli and spinach. Borguini, and Silva (2005) showed that both cultivars of tomatos did not show significant differences between the organic and conventionally grown tomatoes. The values of $\mathrm{pH}$, total soluble solids and titratable acidity indicated differences for organic and conventional tomatoes. Theuer (2006) grew organic and conventional tomatoes in Florida in December 2003 and January 2005. In each year, insignificant differences in color or total soluble solids were detected between treatments. Brandt and Molgaard (2001) suggested that organic crops could contain 10-50\% more phytochemicals than non-organic one. Caris-Veyratet al. (2004) and Chassyet al. (2006) found that organic tomatoes had higher vitamin $\mathrm{C}$, carotenoids, and polyphenol contents (except for chlorogenic acid) soluble solids, flavonoids than conventional tomatoes (on fresh weight). However no significant difference was found for lycopene and naringenin (on dry weight).Barrett et al. (2007) found that the tomato juice prepared from organically produced tomatoes was significantly higher in soluble solids (degrees Brix), consistency, and titratable acidity, but lower in red color, ascorbic acid, and total phenolics content in the micro waved juice. Hallmann, et al (2007) showed that organic tomatoes contained more total and reducing sugars and organic acids. Moreover, in the organic fruits, significantly more bioactive compounds such as ascorbic acid, $\beta$-carotene, flavonols and phenolic acids were found. Only the content of lycopene was higher in the conventional fruits. Faller and Fialho (2010) and Ige (2012) reported an increase in nutrients from organic production practices particularly organic acids and polyphenolic compounds. Duarte et al. (2012) found that Fruits from organic farming had a higher level of vitamin C, compared with fruits from conventional production. In most cases, concentration of organic acids (citric, malic, tartaric, ascorbic and malonic) was higher in the citrus fruits from organic farming.Mohamed and Abdu (2004) reported that organic fertilizers had an improving effect on volatile oil percentage and yield, which could be due to the nutrient content of the organic matter. According to Msaadaet al. (2007) maturation stages play an important factor influencing essential oil composition, while suitable environmental and agricultural practices would 
also help in improving oil yield and quality. Tajidinet al. (2012) concluded that there were significant effects of maturity stages on essential oil and citral contents. The citral content decreased by $5.4 \%$ when lemongrass was harvested at 6.5 compared to at 7.5 months after planting. Thus, maturity stage at harvest influenced essential oil andcitral contents of lemongrass. Dastjerdiet al. (2013) obtained the maximum height of fennel; number of nodes, dry weight and essential oil yield by applying biofertilizer as compared to no fertilization treatment. Gajbhiyeet al. (2013) indicated that the percent essential oil content and oil yield was significantly increased due to individual effect of Farm Yard Manure and NPK levels.

Therefore the present work was aimed to study the impact of organic agriculture on the physical and chemical characteristic of some vegetable, fruits and medicinal crops. In addition the main differences between the quality characteristic of these crops and those cultivated under conventional system were also studied.

\section{MATERIALS AND METHODS}

Fresh orange fruits, tomato and green beans as well as fennel and lemon grass were collected from organic farms (Mafa and Adlia) and conventional farms(Maghrabi and Mansour) at February 2013.The samples were packed in polyethylene bags and kept in refrigerator at $3-4^{\circ} \mathrm{c}$.and till analysis.

\section{1-Preparationof samples for analysis} at $-18^{\circ} \mathrm{C}$.

Orange juice was extracted using electric juice extractor, then frozen

Tomatoes were chopped and the pulp were extracted using electric blender, then frozen at $-18^{\circ} \mathrm{C}$ Green beans (pods containing the beans) were chopped then frozen at $-18^{\circ} \mathrm{C}$ until analysis.

Fennel and lemon grass leaves were dried at $\left(25^{\circ} \mathrm{c}\right)$. Dried fennel seeds and lemon grass were used for essential oil extraction according to the (British Pharmacopeia 1963).

\section{2- Chemical analysis:}

The percentage of total soluble solids (TSS), $\mathrm{pH}$, moisture, ash, fiber ,protein, starch and carotenoids were determined according to the official methods of the (AOAC, 2005).

Titratable acidity was determined as described by (AOAC, 1999). Reducing sugars and non-reducing sugars according to (Miller, 1959). Pectin fractions (Sobotka et al.1972). Total phenol (Singleton and Rossi 1965).Ascorbic (Ranganna1978), and Citric acid Sigmann and wheeler.2004)were determined in the studied samples.

The main constituents of each essential oil were analyzed using GCMS analysis (Adams 1995).

Sensory evaluation: The fresh orange juice were sensory evaluated for color, taste, odor and texture by using 10 panelists from Food Sci. Dept., Fac., Agric., Cairo University according to Carbonellet al., 2007. 
5-Statistical analysis was carried out according to Snedecor and Cochran (1994).

\section{RESULTS AND DISCUSSION}

Impact of organic management on fruit quality:

1. Effect on orange fruit quality:

a-Physical characteristics of fresh orange fruits:

Table (1) shows some selected physical characteristics of orange fruits grown in the selected organic and conventional farms.

The table shows that there were in significant differences in the number of orange fruits $/ \mathrm{kg}$ between organic and conventional farms at west of Delta region, whereas in the east of Delta region i.eAdlia organic farm produced lower number of orange fruits $/ \mathrm{kg}$ than did Mansour conventional farm.

Table (1). Physical characteristics of fresh orange fruits collected from organic and conventional farms at west and east of Delta

\begin{tabular}{|l|c|c|c|c|}
\hline \multirow{2}{*}{ Parameters } & \multicolumn{2}{|c|}{ West of Delta } & \multicolumn{2}{c|}{ East of Delta } \\
\cline { 2 - 5 } & $\begin{array}{c}\text { Mafa } \\
\text { Organic }\end{array}$ & $\begin{array}{c}\text { Maghrabi } \\
\text { conventional }\end{array}$ & Adlia organic & $\begin{array}{c}\text { Mansour } \\
\text { conventional }\end{array}$ \\
\hline $\begin{array}{l}\text { Number of fruits } \\
\text { /kg }\end{array}$ & 5 & 5 & 4 & 5 \\
\hline $\begin{array}{l}\text { weight of peels } \\
\%\end{array}$ & $44.3^{\mathrm{b}} \pm 4.19$ & $49.6^{\mathrm{a}} \pm 5.44^{\mathrm{a}}$ & $43.6^{\mathrm{b}} \pm 8.19$ & $46.7^{\mathrm{a}} \pm 6.09$ \\
\hline juice \% & $55.7^{\mathrm{a}} \pm 4.59$ & $50.4^{\mathrm{b}} \pm 5.69$ & $56.4^{\mathrm{a}} \pm 8.89$ & $53.3^{\mathrm{a}} \pm 7.19$ \\
\hline pH & $3.41^{\mathrm{b}} \pm 0.09$ & $4.08^{\mathrm{a}} \pm 0.19$ & $4.13^{\mathrm{a}} \pm 0.11$ & $4.19^{\mathrm{a}} \pm 0.13$ \\
\hline TSS\% & $12^{\mathrm{a}} \pm 1.09$ & $9.2^{\mathrm{b}} \pm 0.99$ & $10^{\mathrm{b}} \pm 1.05$ & $11^{\mathrm{a}} \pm 1.11$ \\
\hline
\end{tabular}

Result in Table 1 also shows a significant increase in percentage of orange juice in the tested organic farms compared to those in conventional one. The positive effect of organic management on orange juice varied between the two organic farms. Several authors (Lester et al., 2007) found that organic citrus fruits had greater juice percentage. Roussos (2011) reported that fruit size and juice volume were higher under organic farming system. Moreover Peck et al. (2006) showed that organic fruits might be larger in size but smaller ones have also been recorded. 
b-The shelf life of the extracted orange and tomato juice as well as green beans at either room temperature or at $4^{\circ} \mathrm{C}$ was tested as presented in the following table (Table 2)

Table (2). Shelf life of orange juice, tomato juice and beans at $4^{\circ} \mathrm{C}$ and at room temperature $\left(25^{\circ} \mathrm{C}\right)$.

\begin{tabular}{|c|c|c|c|c|c|c|c|c|}
\hline \hline \multirow{2}{*}{ Crops } & \multicolumn{7}{|c|}{ Shelf life/ days } \\
\cline { 2 - 9 } & \multicolumn{2}{|c|}{ Mafa Organic } & \multicolumn{2}{|c|}{$\begin{array}{c}\text { Maghrabi } \\
\text { conventional }\end{array}$} & \multicolumn{2}{|c|}{ Adlia Organic } & Mansour conventional \\
\hline & $4{ }^{\circ} \mathrm{C}$ & $25{ }^{\circ} \mathrm{C}$ & $4{ }^{\circ} \mathrm{C}$ & $25^{\circ} \mathrm{C}$ & $4{ }^{\circ} \mathrm{C}$ & $25^{\circ} \mathrm{C}$ & $4{ }^{\circ} \mathrm{C}$ & $2{ }^{\circ} \mathrm{C}$ \\
\hline Orange juice & 14 & 2 & 10 & 2 & 12 & 2 & 10 & 2 \\
\hline Tomato juice & - & - & - & - & 9 & 2 & 7 & 2 \\
\hline Green beans & - & - & - & - & 20 & 4 & 7 & 4 \\
\hline
\end{tabular}

Results in Table 2shows that the shelf life of organic orange juice, tomato and green beans was increased at $4^{\circ} \mathrm{C}$ compared to that of conventional one. This could be due to the phytochemical content in these organic crops compared to those in conventional one.

c-Chemical and Phytochemical characteristics of fresh orange juice:

Chemical and phytochemical characteristics of orange juice grown inorganic and conventionally managed farms are presented in Table 3.

The Table shows that the effect of organic management on chemical constituents of orange juice is inconsistent. In case of west of the Delta farms, organic management increased juice acidity, decreased the reducing and total sugars content, and had no effect on pectin content. A different trend was found in case of east of the Delta farms. Ithad similar acidity, higher pectin and total sugar, and lower reducing sugars as compared to the conventional one. Thus, it is very difficult to draw a definite conclusion on the impact of organic farming on the chemical components of the orange juice especially major one. Heckeet al 2006 found that the total sugar content of most cultivars ranged between 115 and $160 \mathrm{~g} / \mathrm{kg}$. Some cultivars from organic growing reached higher values.

Phytochemicals represent an important quality parameter because of their positive effect on human health. An inconsistent effect of organic management was also found in case of the phytochemicals constituents in orange juice. Table 3 shows that phenol content of orange juice for both organic farms ( Mafa and Adlia) did not significantly differ than that of conventional farms (Maghrabi and Mansour). Also, organic management increased significantly the ascorbic acid content of orange juice in both organic farms as compared to conventional farms. Moreover, Carotenoids and citric acid contents were decreased and malic acid increased by organic management in case of Mafa farm, while they were not affected in case of Adlia farm.

Results also show that the contents of all phytochemical constituents, except phenol, in orange juice obtained from west of the Delta organic and conventional orchards were higher than those obtained from east of the Delta orchards. Phenol content showed an opposite trend. Here again the 
phytochemical characteristics of the orange fruits seemed to be greatly influenced by the agro ecological zone. This indicates again that there is no clear trend in the response ofCarotenoids , malic, and citric acids contents in response to organic management systems. Tarozziet al. (2006) found high phenolic content in organically managed red orange varieties, while Peck et al. (2009) and Valavanidiset al. (2009) did not find any consistent differences in phenolic compounds' concentration or antioxidant capacity between organic and conventional apple fruits.Brand and Molgaard (2001) suggested that organic produce could contain $10-50 \%$ more phytochemicals than nonorganic one. Faller and Fialho (2010) showed that organic fruits tended to have higher hydrolysable polyphenol contents than conventional ones.

Table (3):Chemical and phytochemical characteristics of fresh orange juice collected from the west and east of Delta

\begin{tabular}{|c|c|c|c|c|c|c|}
\hline \multirow[b]{2}{*}{ Parameters } & \multicolumn{2}{|c|}{ West of Delta } & \multirow[b]{2}{*}{$\begin{array}{l}\text { L.S.D } \\
\text { at } 5 \%\end{array}$} & \multicolumn{2}{|c|}{ East of Delta } & \multirow{2}{*}{$\begin{array}{l}\text { L.S.D } \\
\text { at } 5 \%\end{array}$} \\
\hline & $\begin{array}{l}\text { Mafa } \\
\text { Organic }\end{array}$ & $\begin{array}{l}\text { Maghrabi } \\
\text { conventional }\end{array}$ & & $\begin{array}{c}\text { Adlia } \\
\text { organic }\end{array}$ & $\begin{array}{c}\text { Mansour } \\
\text { conventional }\end{array}$ & \\
\hline Acidity \% & $\begin{array}{l}{ }^{c}{ }^{a} \\
0.19^{2} \\
\pm 0.09\end{array}$ & $0.09^{b} \pm 0.01$ & - & $0.09^{a} \pm 0.08$ & $0.08^{a} \pm 0.08$ & - \\
\hline Pectin (\%) & $\begin{array}{l}7.78^{a} \\
\pm 0.09\end{array}$ & $7.85^{a} \pm 0.89$ & - & $8.34^{a} \pm 0.99$ & $7.90^{b} \pm 0.59$ & - \\
\hline $\begin{array}{l}\text { Reducing } \\
\text { Sugars(g/100gm) }\end{array}$ & $\begin{array}{l}1.23^{\mathrm{b}} \\
\pm 0.06\end{array}$ & $2.06^{\mathrm{a}} \pm 0.07$ & - & $0.75^{b} \pm 0.05$ & $0.82^{a} \pm 0.02$ & - \\
\hline $\begin{array}{l}\text { Total sugars } \\
\text { (g/100gm) }\end{array}$ & $\begin{array}{l}12.40^{\mathrm{b}} \\
\pm 1.22\end{array}$ & $15.44^{a} \pm 1.09$ & - & $\begin{array}{l}12.77^{\mathrm{a}} \\
\pm 1.39\end{array}$ & $11.54^{\mathrm{b}} \pm 1.19$ & - \\
\hline $\begin{array}{l}\text { Total } \\
\text { phenol(mg/100g) }\end{array}$ & $\begin{array}{l}7^{a} \\
7.05^{2} \\
\pm 0.12 \\
\end{array}$ & $7.6^{a} \pm 0.11$ & 0.12 & $9.0 \pm 0.29^{a}$ & $9.1^{\mathrm{a}} \pm 0.21$ & 0.33 \\
\hline Carotenoids $\mu \mathrm{g} / \mathrm{g}$ & $10^{\mathrm{b}} \pm 1.05$ & $11^{a} \pm 1.11$ & 0.11 & $8.61^{\mathrm{a}} \pm 0.19$ & $7.95^{\mathrm{b}} \pm 0.22$ & 0.18 \\
\hline Malic acid\% & $\begin{array}{l}{ }^{a} \\
8.34 \\
\pm 0.99 \\
\end{array}$ & $7.90^{b} \pm 0.59$ & 0.08 & $0.04^{a} \pm 0.09$ & $0.05^{a} \pm 0.09$ & 0.09 \\
\hline Citric acid \% & $\begin{array}{l}{ }^{c} \mathrm{~b} \\
0.75 \\
\pm 0.05\end{array}$ & $0.82^{a} \pm 0.02$ & 0.23 & $0.41^{a} \pm 0.08$ & $0.39^{a} \pm 0.04$ & 0.07 \\
\hline $\begin{array}{l}\text { Ascorbic acid } \\
\mathrm{mg} / 100 \mathrm{~g}\end{array}$ & $\begin{array}{l}68.9^{a} \\
\pm 2.09\end{array}$ & $49.9^{b} \pm 3.09$ & 1.03 & $51.3^{a} \pm 3.44$ & $46.6^{\mathrm{b}} \pm 3.89$ & 1.32 \\
\hline
\end{tabular}

Eschet al (2010) studied the nutritional difference, as determined by vitamin $\mathrm{C}$ content, between six sets of conventionally and organically grown fruits (kiwi ,mango, lemon, orange, gala apple and red delicious apple). There was insignificant difference found in five of the six fruits considered. Only organic lemons displayed a significantly higher vitamin $\mathrm{C}$ level than their conventionally grown counterparts.

Roussos (2011) reported that fruit size and juice volume were higher under organic farming system. There were no any significant differences concerning either the carbohydrates' or organic acids' and total phenol, and the total flavonoid concentration of the juice, However, $\beta$-carotene 
concentration was detected in higher concentration in organically produced fruit.

d- Sensory evaluation of fresh orange juice:

Sensory evaluation of fresh orange juice samples are presented in Table 4

Results show that Mafa organic orange juice received highest panelist scores for taste, odor and texture and lowest scores for the color compared to Maghrabi conventional orange juice. The color and texture in Adlia organic orange juice received higher panelist scores and almost similar score for taste and odor as compared to Mansour conventional orange juice. Generally the Overall sensory scores of orange juice was significantly higher than that of the conventional one.

Table (4). Sensory evaluation of fresh orange juice collected from organic and conventional farms at west and east of Delta

\begin{tabular}{|l|c|c|c|c|}
\hline \multirow{2}{*}{ Farm } & \multicolumn{2}{|c|}{ West of Delta } & \multicolumn{2}{c|}{ East of Delta } \\
\cline { 2 - 5 } & $\begin{array}{c}\text { Mafa } \\
\text { Organic }\end{array}$ & $\begin{array}{c}\text { Maghrabi } \\
\text { conventional }\end{array}$ & Adia Organic & $\begin{array}{c}\text { Mansour } \\
\text { conventional }\end{array}$ \\
\hline Color (25) & $20.0^{\mathrm{b}} \pm 1.10$ & $23.1^{\mathrm{a}} \pm 0.14$ & $24.5^{\mathrm{a}} \pm 1.00$ & $22.0^{\mathrm{b}} \pm 2.11$ \\
\hline Taste (25) & $23.7^{\mathrm{a}} \pm 1.00$ & $18^{\mathrm{b}} \pm 0^{\mathrm{b}} \pm 1.21$ & $23.0^{\mathrm{a}} \pm 2.21$ & $22.6^{\mathrm{a}} \pm 1.88$ \\
\hline Oder (25) & $22.7^{\mathrm{a}} \pm 0.99$ & $18.9^{\mathrm{b}} \pm 1.59$ & $24.2^{\mathrm{a}} \pm 1.99$ & $24.2^{\mathrm{a}} \pm 1.17$ \\
\hline Texture (25) & $23.5^{\mathrm{a}} \pm 1.29$ & $19.6^{\mathrm{b}} \pm 0.99$ & $24.2^{\mathrm{a}} \pm 1.12$ & $22.5^{\mathrm{b}} \pm 2.02$ \\
\hline Total score & $89.8^{\mathrm{a}} \pm 2.12$ & $79.6^{\mathrm{b}} \pm 2.44$ & $95.9^{\mathrm{a}} \pm 2.17$ & $91.3^{\mathrm{b}} \pm 3.18$ \\
\hline
\end{tabular}

Bordeleauet al. (2002) concluded that, in general, there was no trend of better taste in organic fruits or vegetables. Lisa House( 2013) identified sensory differences between the organic and conventional juice with respect to flavor and sweetness -Overall sensory scores (sum of all sensory attributes) were not significantly different.

2-Effect on fresh vegetables quality:

1-Fresh tomato fruits

Physical and chemical characteristics of fresh tomato fruits are illustrated in Table 5. 
Table (5). Physical and chemical characteristics of tomato fruits

\begin{tabular}{|l|c|c|c|}
\hline parameter & Adlia organic & conventional & L.S.D at 5\% \\
\hline Peels and pulp \% & $52.1^{\mathrm{b}} \pm 4.09$ & $60.5^{\mathrm{a}} \pm 5.22$ & 1.12 \\
\hline juice \% & $47.9^{\mathrm{a}} \pm 7.44$ & $39.5^{\mathrm{b}} \pm 5.88$ & 2.01 \\
\hline $\mathrm{pH}$ & $4.39^{\mathrm{a}} \pm 0.19$ & $4.47^{\mathrm{a}} \pm 0.21$ & 0.47 \\
\hline Acidity \% & $0.06^{\mathrm{a}} \pm 0.04$ & $0.07^{\mathrm{a}} \pm 0.05$ & 0.09 \\
\hline TSS\% & $5.5^{\mathrm{b}} \pm 0.19$ & $6.5^{\mathrm{a}} \pm 0.59$ & 0.32 \\
\hline Citric acid \% & $0.44^{\mathrm{a}} \pm 0.11$ & $0.46^{\mathrm{a}} \pm 0.19$ & 0.17 \\
\hline Ascorbic acid $\mathrm{mg} / 100 \mathrm{~g}$ & $31.8^{\mathrm{a}} \pm 1.22$ & $26.7^{\mathrm{b}} \pm 2.03$ & 0.43 \\
\hline Total phenol(mg/100g) & $7.9^{\mathrm{a}} \pm 0.19$ & $7.7^{\mathrm{a}} \pm 0.29$ & 0.11 \\
\hline Lycopene $(\mathrm{mg} / 100 \mathrm{ml})$ & $0.30^{\mathrm{a}} \pm 0.05$ & $0.23^{\mathrm{b}} \pm 0.04$ & 0.08 \\
\hline
\end{tabular}

Results in Table 5 show that organic management significantly increased percentage of pulp juice, ascorbic acid and lycopene and decreased TSS\% compared to conventional management. On the other hand no significant differences were recorded in $\mathrm{pH}$, acidity, citric acid and total phenol between organic and conventional tomato.Caris-Veyratet al., 2004 showed higher lycopene content in organic tomato compared to conventional one. Barrett et al., (2007) analyzed 4 tomato farms under organic and conventional system. The tomato juice prepared from organically product in some farms was significantly higher in soluble solids (degrees Brix), in consistency, and titratable acidity, but lower in red color, ascorbic acid, and total phenolics content.

\section{2-Green beans}

Physical and chemical characteristics of green beans are presented in Table 6 .

Table (6) Physical and chemical characteristics of beans

\begin{tabular}{|l|c|c|c|}
\hline parameter & Adlia organic & $\begin{array}{c}\text { Sharqya } \\
\text { conventional }\end{array}$ & L.S.D at 5\% \\
\hline Citric acid \% & $0.11^{\mathrm{a}} \pm 0.07$ & $0.12^{\mathrm{a}} \pm 0.03$ & 0.04 \\
\hline Protein \% & $2.35^{\mathrm{a}} \pm 0.09$ & $1.7^{\mathrm{b}} \pm 0.09$ & 0.17 \\
\hline Starch \% & $3.12^{\mathrm{a}} \pm 0.01$ & $2.2^{\mathrm{b}} \pm 0.07$ & 0.13 \\
\hline $\begin{array}{l}\text { Reducing Sugars } \\
\text { (g/100gm) }\end{array}$ & $0.42^{\mathrm{a}} \pm 0.04$ & $0.29^{\mathrm{b}} \pm 0.07$ & 0.22 \\
\hline $\begin{array}{l}\text { Total sugars } \\
\text { (g/100gm) }\end{array}$ & $4.206^{\mathrm{a}} \pm 0.11$ & $3.123^{\mathrm{b}} \pm 0.19$ & 0.32 \\
\hline
\end{tabular}

Result in (Table 6) showno significant difference in citric acid between organic and conventional green beans. While protein, starch, reducing sugars and total phenol contentwere significant higher inorganic beans compared to conventional one. 
Worthington (2001) found that organic crops contained significantly more vitamin $\mathrm{C}$, iron, magnesium, and phosphorus and significantly less nitrates than conventional crops. There were no significant trends showing less protein but of a better quality (as measured by essential amino acid content) in organic crops compared to conventional ones.

From the above results it could be concluded that

- Organic management decreased the percentage of peels and reducing sugars increased juice percentages and ascorbic acid in organic orange fruits. In addition organic orange juice had better taste, odor and texture.

- Organic management decreased the weight of peel and pulp and the percentage of TSS and increased juice percentage and the content of ascorbic acid, total phenol and lycopen in tomato as compared to conventional management.

- Organic management of green beans increased percentage of protin, starch, reducing sugar and total sugar compared to conventional management.

\section{Effect on oil quality of medicinal crops:}

\section{1-Lemongrass :}

The essential oil percentage and their components for organic and conventional lemon grass are presented in Table 7.

Table (7) Main components of essential oil in lemon grass collected from Adlia organic farm and the conventional sample collected from the market

\begin{tabular}{|c|c|c|c|c|c|c|}
\hline \multirow{2}{*}{\multicolumn{2}{|c|}{ Agriculture system }} & \multirow{3}{*}{$\begin{array}{c}\begin{array}{c}\text { Essential } \\
\text { oil\% } \\
\mathrm{ml} / \mathbf{1 0 0 g m}\end{array} \\
0.96 \\
\end{array}$} & \multicolumn{4}{|c|}{ Active Substance } \\
\hline & & & \multirow{2}{*}{$\begin{array}{c}\text { a-Myrcene } \\
1.49 \\
\end{array}$} & \multirow{2}{*}{$\begin{array}{r}\text { Citral } \\
96.6 \\
\end{array}$} & \multirow{2}{*}{$\begin{array}{c}\begin{array}{c}\text { Anethole } \\
\text { (Estragole) }\end{array} \\
- \\
\end{array}$} & \multirow{2}{*}{$\begin{array}{c}\text { Total \% } \\
98.1 \\
\end{array}$} \\
\hline \multirow{3}{*}{$\begin{array}{l}\text { Organic } \\
\text { production }\end{array}$} & $\begin{array}{l}\text { Feb - } \\
2013 \\
\end{array}$ & & & & & \\
\hline & $\begin{array}{l}\text { Mar - } \\
2013 \\
\end{array}$ & 0.94 & 15.71 & 82.3 & ------ & 98.0 \\
\hline & $\begin{array}{l}\text { May - } \\
2013 \\
\end{array}$ & 1.28 & 16.0 & 64.0 & 17.3 & 97.2 \\
\hline \multicolumn{2}{|c|}{$\begin{array}{c}\text { Conventional } \\
\text { production }\end{array}$} & 0.54 & - & 59.8 & 20.8 & 80.6 \\
\hline
\end{tabular}

Results show that the organic management increased the oil percentage of lemongrass by 2.5 times as compared to conventional management.

The major components of lemon grass essential oil were (aMyrcene, Citral and Anethole (Estragole)), while they wereCitral and Anethole (Estragole) in the conventional product. Thus, conventional lemon grass essential oil was completely free from a-myrcene compared to organic one. The Citral was the main essential oil component in both of organic and conventional product. The percentage of different components in the essential oil of the organic product varied according to maturation stage(harvesting date). Anethole content which was absent at the earlier harvesting dates, was found in the last harvest in May and reached a value of $17.3 \%$. The data show that the observed increase in a-Myrcenein the second 
date of harvesting was on the expense of Citralwhereas, at the last harvesting date Anethole was the only component increased on the exponse of the Citral.

Tajidinet al 2011 found a significant effect of maturity stages on essential oilpercentage and component. They confirmed that lemongrass harvested at 5.5 and 6.5 months after planting had significantly higher oil contents than those harvested at 7.5 months.

2-Fennel :

The yield of essential oil and their components for organic and conventional Fennelare presented in Table 8

Table (8): The main components of essential oil in fennel seeds collected from Adlia organic farm and the conventional sample collected from the market

\begin{tabular}{|l|c|c|c|c|}
\hline \multirow{2}{*}{ Agriculture system } & \multirow{2}{*}{$\begin{array}{c}\text { Essential oil\% } \\
\mathbf{m l} / \mathbf{1 0 0 g m}\end{array}$} & \multicolumn{3}{|c|}{ Active Substance } \\
\cline { 3 - 5 } & 1.7 & 18.33 & 76.62 & 94.95 \\
\hline Organic production & 1.3 & 43.57 & 53.09 & 96.66 \\
\hline $\begin{array}{l}\text { Conventional } \\
\text { production }\end{array}$ & (Estragole) & Total \% \\
\hline
\end{tabular}

Table 8 show that the essential oil percentage of organic fennel was slightly higher than that of the conventional one, being $1.7 \mathrm{ml} / 100 \mathrm{gm}$ and $1.3 \mathrm{ml} / 100 \mathrm{gm}$, respectively. The essential oil of both organic and conventional fennel contained D-Limonene and Anethole (Estragole). The oil of organic fennel had higher percentage of Anethole (76.6\%) and lower percentage of D-Limonene(18.3\%) than that of conventional one, being $53.1 \%$ and $43.57 \%$, respectively.

Salami and Rahimmalek (2013) reported that the major compound of fennel essential oils was anethole.

For the above result it could be concluded that:

- Organic management of lemon grass increased the oil percentage as well as the percentage of a-Myrcene, and Citral and decreased Anethole (Estragole) content as compared to the conventional product.

- Organic management of fennel increased the percentage of Anethole and decreased the percentage of D-Limonene in the oil as compared to conventional one.

\section{REFERENCES}

Adams, R. P. (1995).Identifications of Essential Oil Components by Gas Chromatography/mass Spectroscopy. Carol Stream, IL: Allured Publishers.

AOAC (1999) Official Methods of Analysis. 16th Edition, 5th reversion,AOAC International, Gaithersburg, MD, method 942.15.

AOAC (2005).Official Methods of Analysis of AOAC International, 18th ed. Association of Official Analytical Chemists, Washington, DC. 
Barrett DM, Weakley C, Diaz JV and Watnik M, (2007).Qualitative and nutritional differences in processing tomatoes grown under commercial organic and conventional production systems. J Food Sci72:C441C451

Bordeleau, G., Myers-Smith, I., Midak, M., and Szeremeta, A. (2002). Food Quality: A comparison of organic and conventional fruits and vegetables, p. 79. Ecological Agriculture, Den KongeligeVeterinoerogLandbohøjskole, Denmark.

Borguini, R. G. and Silva, M. V. da (2005). "Physical-chemical and seasonal characteristics of organic tomato in comparison to the conventional tomato."Alimentos e Nutricao16(4): 355-361.

Bourn, D. and Prescott, J., (2002)A comparison of the nutritional value, sensory qualities, and food safety of organically and conventionally produced foods. Crit. Rev. Food Sci. 42:1-34.

Brand K. and Mölgaard J.P. (2001) .Organic agriculture: does it enhance or reduce the nutritional value of plant foods? J. Sci. Food Agr.81, 924931.

British pharmacopeia (1963): Determination of volatile oil in drugs.The pharmaceutionalpress, London.

Carbonell L., Izquierdo L. and Carbonell I. (2007).Sensory analysis of Spanish mandarin juices.Selection of attributes and panel performance. Food Quality and Preference 18: 329-341.

Caris-Veyrat C, Amiot MJ, Tyssandier V, Grasselly D, Buret M, Mikolajczak M, Guilland JC, Bouteloup-Demange C, Borel P. 2004.Influence of organic versus conventional agricultural practice on the antioxidant micro constituent content of tomatoes and derived purees; consequences on antioxidant plasma status in humans. J Agric Food Chem 52:6503-9. conventional produce grown by Minnesota farmers. $\mathrm{J}$ Food Prot 67:894-900.

Cayuela, J.A., Vidueira, J.M., Albi, M.A., and Gutierrez, F., Influence the ecological cultivation of strawberries (Fragaria $x$ Ananassa Cv. Chandler)on the quality of the fruit and on their capacity for conservation, J. Agric.Food Chem., 1997; 45: 1736-40.

Chassy A.W., Bui L., Renaud E. N. C., Van Horn M. and Mitchell A. E. J. (2006) Agric. Food Chem., 54(21) 8244.

Dastjerdi M.A.B., Dehaghi1 M.A., Chaichi M.R., Fotokian M.H., bossaghzadeh Z. (2013) The effects of biological fertilizer and intercropping on some quantity and quality characteristics of fennel (FOENICULUM VULGARE L.) 2nd National Congress on Medicinal Plants: 1388.

Duarte A.M., Caixeirinho D., Miguel M.G. Fernandes M.M. and Marreiros A. SusteloV.andNunes C.( 2012) Organic Acids Concentration in Citrus Juice from Conventional versus Organic Farming.IHC2010-S14.059.

Esch Julia R., Friend Jeffrey R., Kariuki James K. (2010). Determination of the Vitamin C Content of Conventionally and Organically Grown Fruits by Cyclic Voltammetry Int. J. Electrochem. Sci.,5 (2010) 1464 - 1474.

Faller A.L.K. and Fialho E. (2010) Polyphenol content and antioxidant capacity in organic and conventional plant foods Journal of Food Composition and Analysis $23,561-568$. 
Gajbhiye B. R., Momin Y.D. and. Puri A. N.( 2013) Effect of FYM and NPK Fertilization on Growth and Quality Parameters of Lemongrass (Cymbopogonflexuosus), Agricultural Science Research Journals Vol. 3(4), pp. 115-120.

Hallmann, E., Rembialkowska, E. ,Szafirowska, A., Grudzien, K.(2007) [Significance of organic crops in health prevention illustrated by the example of organic paprika (Capsicumannuum)]. RoczPanstwZaklHig) $.58(1):$ p. $77-82$.

Hecke, K., Herbinger, K., Veberic, R., Trobec, M., Toplak, H., Stampar, F., Keppel, H., Grill, D., (2006) Sugar-, acid- and phenol contents in apple cultivars from organic and integrated fruit cultivation. European Journal of Clinical Nutrition. 60(9): p. 1136-1140.

IgeOderonke(2012) Comparison of the Quality aspects of Organic and Conventional Green beans (Phaseolus vulgaris L.). A Master Thesis University of Guelph Plant Agriculture Guelph, Ontario, Canada.

Kumpulainen, J.(2001) Nutritional and toxicological quality comparison between organic and conventionally grown foodstuffs Proc. Int. Fertil. Soc., 472 (2001): 1-20.

Lester, G.E., Manthley, J.A. and Buslig, B.S., (2007). Organic vs conventionally grown Rio Red whole grapefruit and juice: comparison of production inputs, market quality, consumer acceptance, and human health- bioactive compounds. J. Agric. Food Res. 55:4474-4480.

Lisa House(2013) Conventional vs Organic - A Market Research and Sensory Case Study. International Citrus \& Beverage ConferenceClearwaterBeach,FL

Magkos, F., Arvaniti, F.And Zampelas, A. (2003) Organic food: nutritious food or food for thought?A review of the evidence, Int. J. Food Sci. Nutr. 54 (5) (2003), pp. $357-371$.

Miller, Gail Lorenz(1959) Use of dinitrosalicylic acid reagent for determination of reducing sugarAnal. Chem., 31 (3): 426-428.

Mohamed M. A-H. and Abdu M.,(2004) Growth and Oil Production of Fennel (Foeniculumvulgare Mill): Effect of Irrigation and Organic Fertilization. Biological Agriculture and Horticulture, Vol. 22, pp. 31-39.

Msaada, K.; Hosni, K.; Taarit, M.B.; Chahed, T.; Kchouk, M.E.; Marzouk, M. (2007) Changes on essential oil composition of coriander (CoriandrumsativumL.) fruits during three stages of maturity. Food Chem. 102, 1131-1134.

Peck, G.M., Andrews, P.K., Reganold, J.P., and Fellman, J.K. (2006) Apple orchard productivity and fruit quality under organic, conventional and integrated management. Hort. Science, 41(1), 99-107.

Peck, G.M., Merwin, I.A., Watkins, C.B., Chapman, K.W., Padilla-Zakour, O.I., (2009)Maturity and quality of 'liberty' apple fruit under integrated and organic fruit production systems are similar. Hort. Science, 44: $1382-1389$.

Pérez-López, A.J., López-Nicolás, J.M. and Carbonell-Barrachina, A.A. 2007.Effects of organic farming on minerals contents and aroma composition of Clemenules mandarin juice. European Food Res. Technol. 225:255-260.

Ranganna, S.(1978).Manual of Analysis of Fruit and Vegetables Products. Tata McGraw Hill Publishing Co. Limited, New Delhi 94-97 P. 
Roussos P. A.( 2011) Phytochemicals and antioxidant capacity of orange (Citrus sinensis (I.) Osbeck cv. Salustiana) juice produced under organic and integrated farming system in Greece .ScientiaHorticulturae129, 253-258.

Salami M., Rahimmalek M.,(2013) Variation of trans- anethol content in fennel (foeniculumvulgare) during different developmental stage. 2nd National Congress on Medicinal Plants . Tehran- Iran.p.1080.

Sigmann S. B. and Wheeler D. E.(2004)Quantitative Determination of Citric and Ascorbic Acid in Powdered Drink Mixes. Vol. 81 No. 10 October 2004 - Journal of Chemical Education.

Singleton, V. L. and Rossi, J. A. (1965) .Colorimetry of total phenolics with phosphomolybdic-phosphotungstic acid reagents. Am. J. Enol. Vitic., $16: 144-158$.

Snedecor G. A. and Cochran W. G. (1994).Statistical Method.lowa State Univ. Press, Ames.

Sobotka, F. E. ;Watada, A. E. and Diener, R. G. (1972).Effectiveness of the Pressure- Load Meterin Measuring Firmness of Tomato Fruit.Hortscience, 7(1).West Virginia University, Morgantown.

Stracke BA, Rufer CE and Bub A.(2008) Bioavailability and nutritional effects of carotenoids from organically and conventionally produced carrots in healthy men.

Tajidin, N. E., Ahmad, S. H, Rosenani, A. B., Azimah, H. and Munirah, M. 2012. Chemical composition and citral content in lemongrass (Cymbopogoncitratus) essential oil at three maturity stages African Journal of Biotechnology (II), 2685-2693.

Tarozzi A., Hrelia S., Angeloni C., Morroni F., Biagi P., Guardigli M., CantelliForti G., Hrelia P. (2006) Antioxidant effectiveness of organically and non-organically grown red oranges in cell culture systems, Eur. J. Nutr. 45, 152-158.

Theuer R.C.(2006) Do Organic Fruits and Vegetables Taste Better than Conventional Fruits and Vegetables? The organic center. State of Science Review: Taste of Organic Food.

Valavanidis, A., Vlachogianni, T., Psomas, A., Zovolli, A., Siatis, V. (2009) Polyphenolic profile and antioxidant activity of five apple cultivars grown under organic and conventional agricultural practices. Int. J. Food Sci. Technol. 44, 1167-1175.

Worthington V.(2001) Nutritional quality of organic versus conventional fruits,vegetables, and grains. J Alt Comp Med; 7(2): 161-173. 
تأثير الزراعة العضوية على الصفات النوعيـة لبعض الفواكـه والخضر والنباتـات

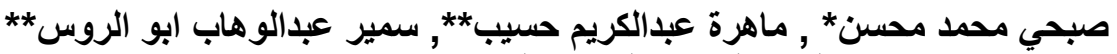

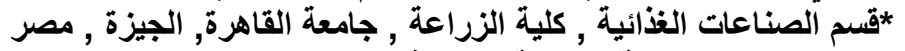

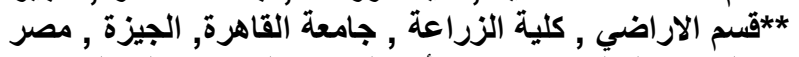

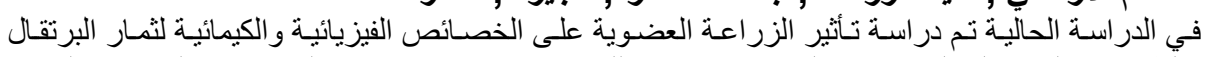

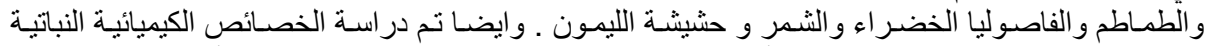

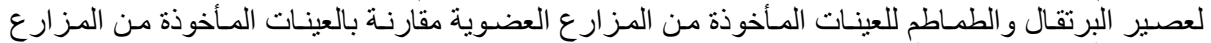

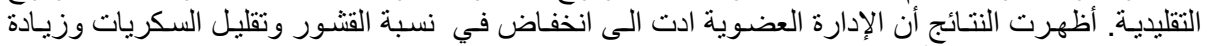

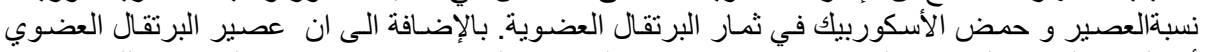

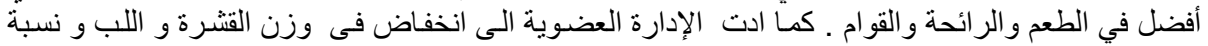

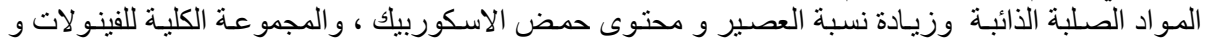

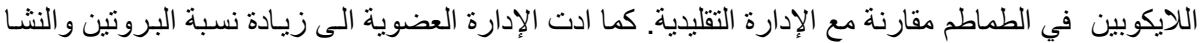

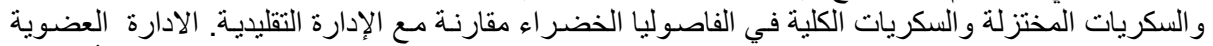

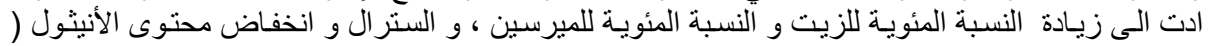

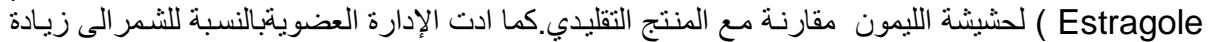
نسبةالأنيثول و انخفاض نسبة D-ليمونين في الزيت مقارنة مع الزراعة الثقليدية.

كلية الزراعة - جامعة المنصورة مركز البحوث الزراعية
قام بتحكيم البحث أ.د / محمد صلاح سيف البرعى البح أ.د / أحمد محمود سعيد حسين 